\title{
Kultur Bakteri Positif pada Pasien dengan Perforasi Gaster di RSUD Dr. Moewardi Surakarta: Sebuah Studi Retrospektif
}

\author{
Muhammad Singgih Nugraha ${ }^{1 *}$, Muhammad David Perdana Putra ${ }^{1}$, Agus Raharjo ${ }^{2}$ \\ 1. Program Pendidikan Dokter Spesialis Bedah, FK Universitas Sebelas Maret, Surakarta \\ Indonesia \\ 2. Departemen Bedah Digestif, RSUD Dr Moewardi, Surakarta, Indonesia
}

Korespondensi : guitarist.bvb@gmail.com

\begin{abstract}
ABSTRAK
Pendahuluan: Perforasi gaster mengakibatkan kebocoran asam lambung kedalam rongga perut, sehingga berkembang menjadi peritonitis kimia. Infeksi bakteri dapat menyertai peritonitis dengan mayoritas patogen penyebab infeksi adalah Enterobacteriaceae sp., Streptococcus sp., dan Bacteroides fragilis. Penelitian ini bertujuan untuk mengetahui profil penderita perforasi gaster dengan kultur bakteri positif di RSUD Dr. Moewardi.

Metode: Pasien diobservasi secara retrospektif dari rekam medis pasien yang didiagnosis perforasi gaster dalam kurun waktu 2017 - 2018.

Hasil: Dalam 2017-2018 ditemukan 84 pasien, 13 diantaranya hasil pemeriksaan kultur positif, onset dilakukan operasi lebih dari 12 jam pada 10 pasien $(77 \%)$ wanita, 3 pasien (23\%) Laki-laki. Sembilan pasien (69\%) diatas umur 40 th, 4 pasien $(31 \%)$ dibawah 40 th. Berdasarkan letak perforasi, 1 pasien $(8 \%)$ di Antrum, 10 pasien $(77 \%)$ di pylorus dan 2 pasien $(15 \%)$ di curvatura mayor. Jenis bakteri yang ditemukan Staphylococcus epidermidis 4 pasien (30\%), Staphylococcus haemoliticus 5 pasien (40\%) dan Enterobacter chloacae 4 pasien $(30 \%)$.

Kesimpulan: Penelitian ini menunjukkan terdapat 13 pasien pemeriksaan kultur positif tanpa ditemukan jenis bakteri yang dominan.
\end{abstract}

Kata Kunci: retrospektif; perforasi gaster; infeksi; kultur bakteri.

\section{ABSTRACT}

Introduction: Gastric perforation results in leakage of stomach acid into the abdominal cavity, thus developing into chemical peritonitis. Bacterial infections can accompany peritonitis with the majority of pathogens causing the infection are Enterobacteriaceae sp., Streptococcus sp., and Bacteroides fragilis. This study aims to determine the profile of patients with gastric perforation with positive bacterial culture in Dr. Moewardi Hospital Surakarta.

Methods: Patients were observed retrospectively from the medical records of patients diagnosed with gastric perforation in the period 2017 - 2018.

Results: In 2017-2018 84 patients were found, 13 of them were positive culture results, the onset of surgery was more than 12 hours in 10 patients (77\%) female, 3 patients $(23 \%)$ male. Nine patients (69\%) were over 40 years old, 4 patients $(31 \%)$ were under 40 years old. Based on the perforation location, 1 patient (8\%) in antrum, 10 patients $(77 \%)$ in pylorus and 2 patients (15\%) in curvatura major. The types of bacteria found were Staphylococcus epdermidis in 4 patients (30\%), Staphylococcus haemoliticus in 5 patients (40\%) and Enterobacter chloacae in 4 patients (30\%).

Conclusion: There were 13 positive culture examination patients. No dominant bacterial type was found.

Keywords: retrospective; gastric perforation; infection; bacterial cultur. 


\section{PENDAHULUAN}

Gaster merupakan bagian dan saluran yang dapat mengembang paling banyak terutama di daerah epigaster, terdiri atas cardia yang berhubungan dengan esofagus melalui orifisium cardia, terletak di bawah diafragma di depan pankreas dan limpa, menempel di sebelah kiri fundus, fundus, antrum dan pilorus dengan orificium pilorik. ${ }^{1,2}$

Perforasi gastrointestinal merupakan suatu bentuk penetrasi yang kompleks dari dinding lambung, usus halus, usus besar akibat dari bocornya isi dari usus ke dalam rongga perut. Perforasi lambung berkembang menjadi suatu peritonitis kimia yang disebabkan karena kebocoran asam lambung ke dalam rongga perut. Perforasi dalam bentuk apapun yang mengenai saluran cerna merupakan suatu kasus kegawatan bedah. Perforasi pada saluran cerna sering disebabkan oleh penyakit-penyakit seperti ulkus gaster, appendisitis, keganasan pada saluran cerna, atau trauma. ${ }^{3}$

Terjadinya perforasi gastrointestinal akan dapat menyebabkan kebocoran makanan dan asam lambung ke dalam rongga abdomen sehingga dapat memicu reaksi inflamasi dan infeksi atau abses. Infeksi bakteri yang menyertai peritonitis biasanya disebabkan oleh patogen antara lain Enterobacteriaceae sp., Streptococcus sp., dan Bacteroides fragilis. Penelitian ini bertujuan untuk mengetahui profil penderita perforasi gaster dengan kultur bakteri positif di RSUD Dr. Moewardi.

\section{METODE}

Penelitian ini termasuk dalam observasional analitik, 13 pasien dilakukan evaluasi dari bulan Januari sampai Agustus 2020. Penelitian ini telah disetujui oleh komite etik dari RSUD Dr. Moewardi dengan nomor 625/III/HREC/2020. Semua pasien perforasi gaster menggunakan total sampling yaitu semua dari populasi pasien perforasi gaster yang memenuhi kriteria penelitian yaitu kriteria yang diambil pada penelitian ini berdasarkan jenis kelamin, kelompok umur berisiko, letak perforasi gaster, onset dan lama operasi serta jenis bakteri.

Spesimen yang didapatkan selama operasi selanjutnya dikultur menggunakan media 5\% sheep blood agar, media untuk bakteri aerobik dan anaerobik. Langkah selanjutnya dilakukan inkubasi. Identifikasi mikroorganisme menggunakan sistem Vitek2.

Data yang telah terkumpul dikelompokkan sesuai dengan kriteria, kemudian dijabarkan secara deskriptif

\section{HASIL}

Tabel 1. Data Karakteristik pasien $(\mathrm{n}=13)$

\begin{tabular}{llcc}
\hline \multicolumn{2}{l}{ Karakteristik pasien } & Jumlah & $(\%)$ \\
\hline Jenis & Laki-laki & 3 & 23 \\
Kelamin & Perempuan & 10 & 77 \\
Umur & $>40$ tahun & 9 & 69 \\
& $<40$ tahun & 4 & 31 \\
Letak & Antrum & 1 & 8 \\
perforasi & Pilorus & 10 & 77 \\
& Curvatura & 2 & 15 \\
& Mayor & & \\
Waktu & $<2$ jam & 1 & 8 \\
operasi & $>2$ jam & 12 & 92 \\
Jenis & S. Epidermidis & 4 & 30 \\
Bakteri & S. Hemoliticus & 5 & 40 \\
& E. Cloachae & 4 & 30 \\
\hline
\end{tabular}

Data yang diambil secara retrospektif kejadian perforasi gaster di RSUD Dr. Moewardi Surakarta periode 1 Januari 2017 sampai 31 Desember tahun 2018 didapatkan 84 kasus, 13 di antaranya hasil pemeriksaan kultur positif.

\section{PEMBAHASAN}

Dari penelitian di atas didapatkan total jumlah pasien dengan perforasi gaster selama 2 tahun sebanyak 84 pasien, dengan 13 di antaranya didapatkan kultur bakteri positif pada cairan intraabdomen sehingga dapat mengetahui profil yang dimiliki patogen yang 
menyertai perforasi gaster. Dari 13 pasien penderita perforasi gaster tersebut yang berjenis kelamin pria (23\%) lebih sedikit dibandingkan wanita (77\%). Beberapa sumber menyatakan bahwa insiden perforasi gaster pada laki-laki lebih sedikit daripada perempuan. $^{3,5}$ Lebih dari setengah kasus terjadi pada wanita daripada pria, sesuai dengan studi pustaka yang menyatakan bahwa penderita tukak peptik memang banyak terjadi pada wanita. ${ }^{4}$ Karakteristik jenis kelamin sebenarnya bukan merupakan faktor risiko, akan tetapi kemungkinan dipengaruhi oleh kebiasaan pasien itu sendiri seperti kurang menjaga pola makan dan stress sehingga dapat memicu terjadinya ulkus. ${ }^{5}$

Data menunjukkan bahwa pasien perforasi gaster dengan kelompok usia di atas 40 tahun lebih banyak (69\%) daripada usia dibawah 40 tahun (31\%), sesuai dengan kepustakaan bahwa usia puncak kejadian perforasi gaster adalah 40-60 tahun. ${ }^{5,6}$ Usia dewasa berisiko terkena ulkus peptik dikarenakan adanya faktor stres yang berhubungan dengan pekerjaan, makanan yang tidak sehat, dan penggunaan obat golongan NSAID, namun kita tidak bisa menyimpulkan bahwa usia ini merupakan faktor risiko utama terhadap penyakit ulkus peptik karena seperti yang kita ketahui bahwa penyebab utama penyakit tukak peptik adalah infeksi $H$. pylori dan penggunaan NSAID. ${ }^{7,8}$

Perforasi gaster berdasarkan letak, didapatkan jumlah perforasi di bagian antrum (8\%), pilorus $(77 \%)$, dan curvatura mayor $(15 \%)$. Hal ini sesuai dengan kepustakaan yang menyatakan bahwa lokasi terjadinya perforasi gaster yang disebabkan karena ulkus peptikum banyak terjadi pada bagian prepyloric sebesar 40\%, sedangkan pada antrum 5\%. Dapat juga terjadi pada bagian curvatura mayor tetapi angka kejadiannya kurang dari $5 \% .^{10}$

Onset operasi yang lebih dari 12 jam, dari sampel menunjukkan angka mutlak terhadap pertumbuhan kuman, hal ini sejalan dengan teori fase infeksi abdomen. Teori menunjukkan bahwa jika pasien belum dilakukan operasi, setelah 12-24 jam akan terjadi infeksi intraabdomen. ${ }^{8,9}$

Durasi operasi lebih dari 2 jam memiliki kecenderungan (92\%) lebih tinggi terkena infeksi bakteri dibandingkan dengan operasi yang lebih cepat (8\%). Sesuai dengan penelitian Hang Ceng et al., bahwa durasi operasi yang semakin lama meningkatkan risiko terjadinya infeksi pada area operasi. ${ }^{10}$

Jenis kuman yang tumbuh pada biakan cairan intra abdomen, didapatkan $S$. epidermidis pada 4 pasien, S. haemoliticus pada 5 pasien, dan E. chloacae pada 4 pasien. ${ }^{9}$

Kultur terhadap mikroorganisme menggunakan media 5\% sheep blood agar efektif untuk mengidentifikasi patogen penyebab perforasi gaster perlu dilakukan guna mengetahui jenis patogen. Setelah mengetahui patogen penyebab, uji sensitivitas terhadap jenis antibiotik juga perlu dilakukan dalam penatalaksanaan kasus perforasi gaster. Selain itu hasil kultur dan uji sensitivitas juga berguna dalam mengurangi risiko serta komplikasi yang dapat ditimbulkan seperti resistensi antibiotik, morbiditas, maupun angka kekambuhan kasus. ${ }^{9,10}$

Tiga mayoritas patogen penyebab infeksi intra abdomen yang berasal dari komunitas adalah Enterobactericeae (Gram negatif), Streptococcus (Gram positif), Bacteroides fragilis (anaerob). Dari penelitian terhadap kasus peritonitis dengan hasil kultur bakteri positif, yang dilakukan di 25 pusat kesehatan di Perancis menunjukkan bahwa 2/3 infeksi dari pusat kesehatan berhubungan dengan Enterobactericeae (gram negatif), dan $1 / 3$ nya Enterococcus sp., dari hasil tersebut didapatkan juga biakan Candida $s p$. yang positif sebanyak $5 \% .^{9,10}$

\section{KESIMPULAN}

Penelitian ini menunjukkan bahwa dalam waktu 2 tahun didapatkan 13 pasien 
dengan pemeriksaan kultur bakteri positif. Pasien kultur positif tersebut didominasi jenis kelamin wanita, dengan umur rerata di atas 40 tahun. Letak perforasi terbanyak di antrum, dengan onset operasi di atas 12 jam, dan lama operasi lebih dari 2 jam. Penelitian ini menun jukkan tidak ditemukan jenis bakteri yang dominan.

\section{DAFTAR PUSTAKA}

1. Brendon, Coventry J. Gastric Surgery.Upper Abdominal Surgery. Springer London Heidelberg New York Dordrecht. 2014; Chapter 4.

2. Riwanto IGN. Lambung dan Duodenum.Buku Ajar Ilmu Bedah.Ed. 2. Penerbit Buku Kedokteran EGC.2003.Jakarta

3. Buck DL, Vester-Andersen M, Moller MH,. Accuracy of clinical prediction rules in peptic ulcer perforation: an observational study. Scandinavian Journal of Gastroenterology, 2012;47(1):28-35

4. Krobot K. Effect of inappropriate initial empiric antibiotic therapy on outcome of patients with community-acquired intraabdominal infections requiring surgery. EurJ Clin Microbiol. 2004;23:682-7.

5. Lopez N, Kobayashi L, Coimbra R,. A Comprehensive review of abdominal infections.Worl J Emerg Surg. 2011;6:7.

6. Menichetti F, Sganga G. Definition and classification of intra-abdominal infections. J Chemother. 2009;21:3-4.

7. Merlino JI, Yowler CJ, Malangoni MA. Nosocomial infections adversely affect the outcomes of patients with serious intraabdominal infections. Surg Infect Larchmt. 2004;5(1):21-7.

8. Plas HVD. Microbiological evaluation and antimicrobial treatment of complicated intraabdominal infections. South Afr J Epidemiol Infect. 2012;27(2):53-7.

9. Prabu V, Shivani A. An Overview of History Pathogenesis and Treatment of perforated peptic ulcer Disease with Evaluation of prognostic Scoring in Adults.Annals of Medical and Health Science Research. 2014;4(1):22-9.
10. Swenson BR, Metzger R, Hedrick TL, McElearney ST, Evans HL, Smith RL, et al. Choosing antibiotics for intra-abdominal infections: what do we mean by"high risk"?. Surg Infect Larchmt. 2009;10(1):29-39 